\title{
Defined Activity Repeat Frequency Code
}

National Cancer Institute

\section{Source}

National Cancer Institute. Defined Activity Repeat Frequency Code. NCI Thesaurus. Code C93755.

A coded value specifying the number of occurrences of an activity within a given time period. 